\begin{tabular}{lr}
\hline \multicolumn{1}{c}{ D Y N A M I C E C O N O M E T R I C } & M O D E L \\
DOI: http://dx.doi.org/10.12775/DEM.2017.002 & Vol. 17 (2017) 19-39 \\
\hline $\begin{array}{l}\text { Submitted June 6, 2017 } \\
\text { Accepted December 4, 2017 }\end{array}$ & ISSN (online) 2450-7067 \\
ISSN (print) 1234-3862
\end{tabular}

\author{
Goksu Aslan*
}

\title{
The Effects of Income Inequality and Redistribution in Democracies: A Dynamic Panel Data Approach**
}

\begin{abstract}
A b stract. In this paper, the simultaneous effects of the inequality and redistribution on economic growth are tested for the whole sample and for a subset of democratic countries, following SYS-GMM estimation on a panel dataset over a period from 1960 to 2010. Overall, net inequality has a negative significant effect on subsequent 5 years for both samples, while redistribution impact is only significant in democracies. The findings are consistent with the fact that governments tend to significantly redistribute more in democracies.
\end{abstract}

K e y w o r d s: democracy; economic growth; inequality; redistribution.

J E L Classification: C23; E62; O40.

\section{Introduction}

The effects of income inequality and redistribution are complex and controversial. Income inequality may affect economic growth both negatively and positively. Furthermore, income inequality and redistribution may interact such that higher inequality may be associated with higher redistribution and this may create pressure on economic growth. This paper handles the simultaneous effects of net inequality and redistribution on economic growth through a dynamic panel data framework and tries to show that inequality is harmful while redistribution is not for the economic growth at least in democracies. The main aim of the paper is to show that in democracies redis-

\footnotetext{
* Correspondence to: Goksu Aslan, University of Messina, Department of Economics, Piazza Pugliatti, 1, 98122 Messina, Italy, e-mail: goksuaslan@goksuaslan.com.

** This work was financed by the University of Messina.

(C) 2017 Nicolaus Copernicus University. All rights reserved. http://www.dem.umk.pl/dem
} 
tribution has the growth-enhancing effect on economic growth and this effect is absolutely larger than the negative effect of income inequality. For this purpose, first, the whole sample and then the democratic sample is particularly observed.

The analyses have been carried out in dynamic panel data frameworks over a period from 1960-2010 for 137 countries of which 112 are democracies. As for the results of the statistical tests for difference in covariance and in mean, there exist differences between democratic and non-democratic samples. Due to the endogeneity and reverse causality problem between regressors and the dependent variable, system generalized method of moments estimation, henceforth SYS-GMM is used. In order to provide the comparisons of the models, ordinary least squares (OLS) and within group (WG) estimations have also been reported.

The results show that net inequality has a negative significant impact on economic growth in both samples, and that redistribution has a positive significant impact on economic growth in the democratic sample. In democracies, the effect of redistribution is larger than the impact of income inequality in absolute terms. According to the estimation results for the whole sample, a rise in the GINI of net income by 10 points leads to a decrease in the growth of real GDP per capita in the range of $0.74-1.10 \%$. However, redistribution impact remains insignificant for the whole sample. In democracies, both net inequality and redistribution impacts are significant. In democracies, net inequality has a negative effect which is strictly significant. A rise in the GINI of net income by 10 points leads to a decrease in the growth of real GDP per capita in the range of $0.84-1.13 \%$. On the other hand, a rise in the redistribution by 10 points leads to an increase in the growth of real GDP per capita in the range $1.27-1.4 \%$.

In countries where income is distributed relatively equally, economic growth benefits from the positive impact of variables related to redistribution. Income inequality, in its different forms, such as Gini index or income shares of deciles of the population, may be harmful to economic growth. Policies reducing inequality, such as higher tax policies, may be also destructive for the economic growth. These effects could differ to the extent of democracy.

Another important issue is that how income inequality change before and after taxes and transfers. If inequality after taxes and transfer, in other words, net inequality, is quite lower than inequality before taxes and transfer; this means that redistributive policies are implemented in the favor of the poor. Inequality effects on economic growth may be handled as before and after taxes, or with the implementation of the effects of redistributive policies 
which may differ to the extent of democracy levels of countries. In order to achieve comparable results for inequality-redistribution-growth relationships, net inequality is used in the analyses.

Section 1 discusses the literature and finds that most authors have reached a similar conclusion. Section 2 devises a new statistical model whereby that conclusion can be confirmed or rejected. Section 3 presents the econometric results. The last section evaluates the results warrant any change in the hitherto conventional conclusion.

\section{Literature Review}

In the inequality and economic growth literature, both negative and positive effects of inequality are mentioned. Inequality which can undermine progress in health and education, causes investment-reducing political and economic instability and undercuts the social consensus required to adjust in the face of shocks. Inequality is also said beneficial for growth, by fostering aggregate savings (Kuznets, 1955; Kaldor, 1956), by promoting high return projects (Rosenzweig and Binswanger, 1993), by stimulating research and development (Foellmi and Zweimüller, 2006). Some inequality is integral to the effective functioning of a market economy and the incentives needed for investment and growth. As for the Okun's (1975) big-trade-off hypothesis, a treatment for inequality as redistributive policies may be also worse for growth than disease itself by creating disincentives and inefficiencies. Inequality is harmful for growth by promoting expensive fiscal policies (Perotti, 1993; Alesina and Rodrik, 1994; Persson and Tabellini, 1994); by inducing an inefficient state bureaucracy (Acemoglu et al., 2011), by hampering human capital formation (Bénabou, 1996); or by undermining the legal system (Glaeser et al., 2003). The paper by Barro (2000) which shows a negative significant inequality impact in developing economies, applying simultaneous equation models and brings complex relationship between inequality and the fertility rate as the negative impact of inequality on economic growth is only significant when the fertility rate is omitted. Voitchovsky (2005), applying a SYS-GMM estimator, shows a negative impact of the Gini coefficient. In connection with the fact that inequality and especially redistribution may have different effects on economic growth, in the following section these effects are discussed in the light of leading studies. 


\subsection{Democracy and Inequality}

The literature on the relationship between democracy and inequality has controversial findings. Sirowy and Inkeles (1990) find that the existing evidence suggest the level of political democracy as measured at one point of time tends not to be widely associated with lower levels of income inequality. They suggest that there may be evidence in favor of the relevance of the history of democracy for inequality. Muller (1988) finds a negative correlation between inequality and the numbers of years a country has been democratic. Simpson (1990), Burkhart (1997) and Gradstein and Justman (1999b) find a nonlinear reduced form relationship between democracy and inequality where at both low and high levels of democracy, inequality is lower, and it is higher at intermediate levels of democracy. However, the impact of the history of democracy identified in the models that do not include fixed effects, it will capture the impact of these omitted fixed effects. This is a special case of the difficulty of identifying duration dependence and unobserved heterogeneity. (Acemoglu et.al, 2009) Recent studies by Li et.al (1998), Rodrik (1999), and Scheve and Stasavage (2010) use better data and exploited the time as well as cross-sectional dimensions. Li et. Al (1998) find that an index of civil liberties is negatively correlated with inequality, such that greater civil liberties are associated with lower inequality, using a pooled OLS. Rodrik (1999) finds a positive correlation between Freedom House of Polity III measure of democracy and both average real wages in manufacturing and the share of wages in national incomes, showing in both a crosssection and a panel of countries using country fixed effects. Also, he finds an evidence that political competition and participation at large are important parts of the mechanisms via which democracy worked. Scheve and Stasavage (2009) use a long-run panel data from 1916 to 2000 for 13 OECD countries with country-specific effects. They find a significant positive correlation between the universal suffrage dummy and the share of income accruing to people between the 90th and 99th percentiles of the income distribution divided by the share accruing to the people above the 99th percentile. Lee (2005) uses an unbalanced panel data with random effects, covering 64 countries for the period from 1970 to 1994 . He finds a significant positive correlation between the size of government measured by tax revenues as a percentage of GDP and democracy, suggesting that for large enough levels of government, democracy reduces inequality. 


\subsection{Democracy and Redistribution}

Meltzer and Richard (1981) find that an expansion of democracy should lead to greater tax revenues and redistribution. Gil et.al (2004) find no correlation between tax revenues and government spending measures and democracy, using a cross-sectional specification. Aidt et.al (2006) and Aidt and Jensen (2009b) observe the impact of democratization measured by the proportion of adults who could vote in a cross-sectional panel. Aidt et.al (2006) observe a cross-sectional panel of 12 West European countries over the period 1830-1938. Aidt and Jensen (2009b) find positive effects of suffrage on government expenditure as percentage of GDP and also tax revenues as a percentage of GDP, using a cross-national panel of 10 West European countries over the period 1860-1938. Democracy is expected to change not only the amount of tax revenues, but also what taxes were used for. One might expect democracies to move towards more progressive taxation (Acemoglu et.al, 2015). Aidt and Jensen (2009b) find that suffrage expansion leads to lower direct taxes and higher indirect taxes. Aidt and Jensen (2009a) find a nonlinear relationship between the introduction of an income tax and suffrage where an expansion of the franchise starting from very restrictive levels reduces the probability that an income tax will be introduced, but also that this probability increases at higher levels of the franchise. Scheve and Stasavage $(2010,2012)$ find no correlation between democracy and either tax progressivity or the rate of capital taxation, using a long-run approach of the OECD countries. Lindert (1994) finds an impact of democracy on various types of social spending in a panel data over the period 1880-1930, stating that "There was so little social spending of any kind before the twentieth century mainly because political voice so restricted." $\mathrm{Hu}$ ber and Stephens (2012) find the story of democracy which is measured by the cumulative years a country has been democratic since 1945 is positively correlated with education spending, health spending, and social security and welfare spending, observing a panel dataset for Latin America over the period 1970-2007. Kaufman and Segura-Ubiergo (2001) find that democracy which is measured by dichotomous measured introduced by Przeworski et.al (2000) is positively correlated with government expenditure on health and education. Brown and Hunter (1999) also show that democracies have greater social spending than autocracies, using democracy measured by Przeworski et.al (2000). Persson and Tabellini (2003) find some evidence that democracy measured by the Gastil index and the Polity score, has positive effects on government expenditure and government revenues, and social security spending as percentage of GDP. An additional focus of the democ- 
racy-redistribution literature is based on whether if female enfranchisement has an additional or differential impact on government taxation or spending. Results from Lindert (1994) showing that financial enfranchisement has an independent impact on social spending are consistent with Aidt and Dallal (2008) for a later period. Lott and Kenny (1999) find that the expansion of women's voting rights in the United States between 1870 and 1940 is associated with increases in per capita government revenues and expenditures. Miller (2008) shows that female suffrage increases health spending and let to significant falls in infant mortality. Aidt and Jensen (2013) provide an identification strategy for the endogeneity of the democracy. They argue that revolutionary threat measured by revolutionary events in other countries is a viable instrument for democracy in a panel of West European countries, building on the theoretical ideas of Acemoglu and Robinson (2000, 2006) and Aidt and Jensen (2011). They find that democracy measured by the extent of suffrage has a robust positive effect on government spending. Acemoglu et.al (2015) explain that the expectation in the literature has been that democracy should increase redistribution and reduce inequality, and why this expectation may not be borne out in the data because democracy may be captured or constrained, because democracy may cater to the wishes of the middle class, or because democracy may be simultaneously open up new economic opportunities to the previously excluded, contributing to economy inequality. They find that democratization increases government taxation and revenue as fractions of GDP, confirming the prediction of the standard Meltzer-Richard model. They do not find a robust evidence that democracy reduces inequality.

\section{Methodology}

\subsection{The Model}

The starting point is the so-called Solow-Swan model which is developed by Islam (1995). This approach allows including unobservable individual country and period-specific effects. The model is estimated as below:

$$
y_{i t}-y_{i, t-5}=\beta_{0}+\beta_{1} y_{i, t-5}+\beta_{2} N_{i t}+\beta_{3} R_{i t}+\delta^{\prime} \chi_{i t}+\eta_{i}+v_{i t}+\xi_{t}
$$

where $y_{i t}-\log$ of real GDP per capita of country $i$ for time $t, y_{i, t-5}-\log$ of real GDP per capita of country $i$ for time $t-5, y_{i t}-y_{i, t-5}-5$-year average growth rate of country $i$ for time $t, N_{i t}$ - initial level of net inequality of country $i$ for time $t, R_{i t}$ - initial level of redistribution of country $i$ for time $t$, 
$\eta_{i}-$ unobserved time invariant country specific effects, $\xi_{t}$ - time effect of period $t, v_{i t}$ - idiosyncratic error term, $\chi_{i t}$ - additional control variables, including investment share, population growth and total education. ${ }^{1}$

\subsection{The Data}

The dataset includes 5-year average observations for 137 countries over a period from 1960 to 2010 . The countries and periods are restricted to the availability of data. The data comes from Penn World Table (PWT) ${ }^{2}$ version 8.0, The Standardized World Income Inequality Database (SWIID) version 5.0, Polity IV Project (2014) and Berg et.al (2014). As regard as several income inequality measures, Gini index is most widely used among them. Income shares of the deciles or quantiles of the population are also highly informative on how income distributed within population. Redistribution is calculated as the difference between market income and net income that is equal the sum of taxes and transfers. ${ }^{3}$ The Standardized World Income Inequality Database (SWIID) which was introduced in 2008 has provided income inequality data that seek to maximize comparability while providing the broadest possible coverage of countries and years. (Solt, 2014) The Polity IV dataset covers all major, independent states in the global system over the period 1800-2013 (i.e., states with a total population of 500,000 or more in the most recent year; currently 167 countries). The "Polity Score" captures this regime authority spectrum on a 21-point scale ranging from -10 (hereditary monarchy) to +10 (consolidated democracy). The Polity scores can also be converted into regime categories in a suggested three-part categorization of "autocracies" ( -10 to -6$)$, "anocracies" $(-5$ to +5$)$, and "democracies" (+6 to +10). (Center for Systemic Peace, 2014)

\footnotetext{
${ }^{1} N_{i, t-s}$ and $R_{i, t-s}$ - lagged terms of independent variables are used as instrument variables.

${ }^{2}$ The Penn World Table (PWT) is a database with information on relative levels of income, output, inputs and productivity, with country and period coverage depending on the release. PWT version 8.0 which is released in 2013 is a database with information on relative levels of income, output, inputs and productivity, covering 167 countries between 1950 and 2011.

${ }^{3}$ Market income is defined as amount of money coming into the household, excluding any government cash or near-cash benefits, the so-called "pre-tax, pre-transfer income". Gross income is the sum of market income and government transfer payments; it is "pre-tax, post-transfer income". Net income, in turn, is gross income minus direct taxes: "post-tax, post-transfer income". Solt (2009)
} 
As regard as the inclusion of control variables, a higher saving rate can sustain a higher level of output per capita as capital accumulation per individual also increases. In turn, the higher rate of saving is associated the richer country, in contrast with the higher rate of population growth. Augmented Solow Growth model associates higher saving rate to higher growth rate of real GDP per capita, higher $n+g+\delta$ to lower growth rate of real GDP per capita, with $g+\delta$ constant and equal to 0.05 across countries. In the analyses, following Mankiw et al. (1992), $g+\delta$ is taken to be equal to 0.05 assuming this value to be the same for all countries. Human capital, particularly as attained through education, to economic progress (Lucas, 1988; Mankiw, Romer and Weil, 1992). An abundance of well-educated people goes along with a high level of labor productivity. It also implies larger numbers of more skilled workers and greater ability to absorb advanced technology from developed countries. The level and distribution of educational attainment also have impact on social outcomes, such as child mortality, fertility, education of children, and income distribution (Barro and Lee, 1994; De Gregorio and Lee, 2002; Breierova and Duflo, 2004; Cutler et al., 2006).

\subsection{The Estimator}

Since the right-hand-side variables are typically endogenous and measured with error, and there are omitted variables, estimating growth regressions becomes problematic. In the presence of omitted variables, least squares parameter estimates are biased (Bond et.al, 2001). Applying OLS creates the problem that $Y_{i, t-5}$ is correlated with the fixed effects in the error term, which causes dynamic panel bias (Nickell, 1981). The difference and system generalized method of moments estimators, hence DIFF-GMM and SYS-GMM respectively, are designed for dynamic panel analysis where current realizations of the dependent variable influenced by past ones in the cases where large $N$, small $T$; there may be arbitrarily distributed fixed individual effects. This argues against cross-section regressions which must essentially assume fixed effects away, and in favor of a panel setup where variation over time can be used to identify parameters. Other problem is to have endogeneity while observing the effects of inequality on economic growth, because of the unavailability of time-variant exogenous regressors. Following the DIFF-GMM and SYS-GMM estimators would be appropriate approach if the instruments are correctly used. The DIFF-GMM and SYSGMM estimators assume that some regressors may be endogenous; the idiosyncratic disturbances (those apart from the fixed effects) may have individual specific patterns of heteroskedasticity and serial correlation; the idiosyn- 
cratic disturbances are uncorrelated across individuals; some regressors can be predetermined but not strictly exogenous. Finally, because the estimators are designed for general use, they do not assume that good instruments are available outside the immediate dataset. In effect, it is assumed that the only available instruments are "internal" - based on lags of the instrumented variables. However, the estimators do allow inclusion of external instruments (Roodman, 2009). Comparing to DIFF-GMM estimator, the SYS-GMM estimator has many advantages as in variables which are random-walk or close to be random-walk (Baum, 2006). By using DIFF-GMM, differencing variables within groups will remove any variable that is constant. SYSGMM produces more efficient and precise estimates compared to DIFFGMM, by improving precision and reducing the finite sample bias (Baltagi, 2008). While working with unbalanced panel as in the panel dataset used in this paper, DIFF-GMM approach would be weak in filling gaps (Roodman, 2006, p.20). The SYS-GMM estimator is unbiased and most efficient if there are endogenous and predetermined regressors. By construction, the residuals of the differenced equation should possess serial correlation, but if the assumption of serial independence in the original errors is warranted, the differenced residuals should not exhibit significant $A R(2)$ behaviour. If a significant $\operatorname{AR}(2)$ statistic is encountered, the second lags of endogenous variables will not be appropriate instruments for their current values (Baum, 2013).

\section{Estimations}

The countries have been grouped into two groups to the extent of their regime authorities, such that countries having Polity IV score greater than 5 defined as democracies and otherwise defined as non-democracies. The analyses cover 137 countries of which 112 are democracies First, the test is conducted to compare means and covariance matrices of these two groups.

Table 1. Test of equality of covariance matrices across two samples

\begin{tabular}{cccc}
\hline Test & Test statistic & Prob. \\
\hline Modified LR chi2 & 231.2813 & & \\
Box F(12,18884415.1) & 19.18 & Prob>F= & 0.000 \\
Box chi2 & 230.11 & Prob>chi2 & 0.000 \\
\hline
\end{tabular}

LR chi-squared, Box's F, Box's chi-squared statistics, and associated pvalues for the equality of covariance matrices are reported in Table 1. According to the test of equality covariance matrices, the covariance matrices 
could not be considered as equal. Assuming heterogeneous covariance matrices, the samples, the equality of means is tested.

Table 2. Test of equality of means of two samples

\begin{tabular}{cccc}
\hline Test & Test statistic & Prob. \\
\hline LR chi2(3) & 68.36 & Prob>chi2 & 0.000 \\
\hline
\end{tabular}

LR chi-squared statistic and associated p-values for the equality of means are reported in Table 2. The null hypothesis of equal means for the samples is rejected. The means of two groups could not be considered as equal.

Table 3. The impact of inequality and redistribution on economic growth SYSGMM estimation - The whole sample

\begin{tabular}{|c|c|c|c|c|c|}
\hline Models & $\begin{array}{c}\text { (1) } \\
\text { Baseline }\end{array}$ & $\begin{array}{c}\text { (2) } \\
\text { Baseline } \\
+ \text { Controls } \\
\end{array}$ & $\begin{array}{c}(3) \\
\text { Baseline } \\
+\quad \text { Controls } \\
\end{array}$ & $\begin{array}{c}(4) \\
\text { Baseline } \\
+\quad \text { Controls } \\
\end{array}$ & $\begin{array}{r}(5) \\
\text { Baseline } \\
+\quad \text { Controls } \\
\end{array}$ \\
\hline In(initial income) & $\begin{array}{c}-0.0163^{\star *} \\
(0.0070)\end{array}$ & $\begin{array}{c}-0.0186^{\star *} \\
(0.0079)\end{array}$ & $\begin{array}{c}-0.0217^{\star \star \star} \\
(0.0072)\end{array}$ & $\begin{array}{c}-0.0264^{\star \star \star} \\
(0.0083)\end{array}$ & $\begin{array}{c}-0.0207^{\star \star \star} \\
(0.0079)\end{array}$ \\
\hline Net inequality & $\begin{array}{c}-0.0930^{* *} \\
(0.0423)\end{array}$ & $\begin{array}{c}-0.1036^{* *} \\
(0.0410)\end{array}$ & $\begin{array}{r}-0.0462 \\
(0.0404)\end{array}$ & $\begin{array}{c}-0.0859^{* *} \\
(0.0354)\end{array}$ & $\begin{array}{c}-0.0735^{*} \\
(0.0429)\end{array}$ \\
\hline Redistribution & $\begin{array}{l}0.0831 \\
(0.0623)\end{array}$ & $\begin{array}{l}0.0701 \\
(0.0706)\end{array}$ & $\begin{array}{l}0.0603 \\
(0.0692)\end{array}$ & $\begin{array}{l}0.0313 \\
(0.0495)\end{array}$ & $\begin{array}{l}0.0624 \\
(0.0698)\end{array}$ \\
\hline $\ln (i)$ & & $\begin{array}{l}0.0181 \\
(0.0158)\end{array}$ & $\begin{array}{c}0.0332^{* *} \\
(0.0150)\end{array}$ & $\begin{array}{c}0.0120 \\
(0.0234)\end{array}$ & \\
\hline $\ln (n)$ & & & $\begin{array}{c}-0.0810^{* *} \\
(0.0384)\end{array}$ & $\begin{array}{c}-0.0063 \\
(0.0365)\end{array}$ & \\
\hline In(total education) & & & & $\begin{array}{l}0.0429 \\
(0.0317)\end{array}$ & \\
\hline $\ln (s)-\ln (n+g+\delta)$ & & & & & $\begin{array}{c}0.0368^{* *} \\
(0.0177)\end{array}$ \\
\hline Constant & $\begin{array}{c}0.1914^{\star * *} \\
(0.0725)\end{array}$ & $\begin{array}{c}0.1612^{* *} \\
(0.0764)\end{array}$ & $\begin{array}{c}0.2658^{* *} \\
(0.1069)\end{array}$ & $\begin{array}{c}0.1680^{* *} \\
(0.0843)\end{array}$ & $\begin{array}{c}0.1775^{\star *} \\
(0.0707)\end{array}$ \\
\hline Observations & 676 & 676 & 676 & 623 & 676 \\
\hline Number of countries & 137 & 137 & 137 & 118 & 137 \\
\hline Hansen & 0.5643 & 0.4586 & 0.6022 & 0.4530 & 0.4629 \\
\hline Difference-in-Hansen & 0.761 & 0.681 & 0.610 & 0.384 & 0.650 \\
\hline AR1 & 0.0000 & 0.0000 & 0.0001 & 0.0002 & 0.0001 \\
\hline AR2 & 0.1195 & 0.1897 & 0.1248 & 0.1868 & 0.1655 \\
\hline Number of instruments & 58 & 58 & 58 & 58 & 58 \\
\hline
\end{tabular}

Notes: The table reports SYS-GMM estimations. All regressions include time dummies; second lags in GMM instruments; robust standard errors in parentheses; AR(1) is the $p$-value on the test for the first order serial correlation in the differenced error terms; $\operatorname{AR}(2)$ is the $p$-value on the test for the second order serial correlation in the differenced error terms; Hansen denotes the $p$-value on the test for the validity of the full instrument set; Difference-in-Hansen denotes the $p$-value for the validity of the set of levelequation. $* * *, * *, *$ denote significance at the 1,5 , and $10 \%$ levels, respectively. 
The results from the SYS-GMM estimations are presented in Table 3 for the whole sample. The results from the OLS and WG estimations are documented in Appendix in Table 2.1a and 2.1b respectively for comparison.

For the whole sample, net inequality has a negative significant impact on economic growth. A rise in the GINI of net income by 10 points leads to a decrease in the growth of real GDP per capita in the range of $0.74-1.10 \%$. However, redistribution impact remains insignificant for the whole sample.

The results from the SYS-GMM estimations for democracies are presented in Table 4. The results from the OLS and WG estimations are documented in Appendix in Table 3.1a and 3.1b respectively for comparison.

Table 4. The impact of inequality and redistribution on economic growth SYSGMM estimation - Sub-group of democracies

\begin{tabular}{|c|c|c|c|c|c|}
\hline Models & $\begin{array}{c}\text { (1) } \\
\text { Baseline }\end{array}$ & $\begin{array}{c}\text { (2) } \\
\text { Baseline } \\
+ \text { Controls }\end{array}$ & $\begin{array}{c}(3) \\
\text { Baseline } \\
+ \text { Controls }\end{array}$ & $\begin{array}{c}(4) \\
\text { Baseline } \\
+ \text { Controls }\end{array}$ & $\begin{array}{c}(5) \\
\text { Baseline } \\
+ \text { Controls }\end{array}$ \\
\hline In(initial income) & $\begin{array}{c}-0.0276^{* * *} \\
(0.0078)\end{array}$ & $\begin{array}{c}-0.0278^{* * *} \\
(0.0080)\end{array}$ & $\begin{array}{c}-0.0333^{* * *} \\
(0.0104)\end{array}$ & $\begin{array}{c}-0.0275^{\star * *} \\
(0.0081)\end{array}$ & $\begin{array}{c}-0.0292^{* * *} \\
(0.0081)\end{array}$ \\
\hline Net inequality & $\begin{array}{c}-0.1134^{* *} \\
(0.0479)\end{array}$ & $\begin{array}{c}-0.1126^{* * *} \\
(0.0400)\end{array}$ & $\begin{array}{c}-0.1222^{* *} \\
(0.0614)\end{array}$ & $\begin{array}{c}-0.0888^{*} \\
(0.0473)\end{array}$ & $\begin{array}{c}-0.0877^{* *} \\
(0.0393)\end{array}$ \\
\hline Redistribution & $\begin{array}{c}0.1408^{* *} \\
(0.0588)\end{array}$ & $\begin{array}{l}0.1265^{* *} \\
(0.0567)\end{array}$ & $\begin{array}{c}0.1645^{\star *} \\
(0.0739)\end{array}$ & $\begin{array}{c}0.0934 \\
(0.0659)\end{array}$ & $\begin{array}{l}0.1314^{* *} \\
(0.0569)\end{array}$ \\
\hline $\ln (\mathrm{i})$ & & $\begin{array}{l}0.0398^{*} \\
(0.0225)\end{array}$ & $\begin{array}{c}0.0507^{* *} \\
(0.0199)\end{array}$ & $\begin{array}{c}0.0561^{* * *} \\
(0.0160)\end{array}$ & \\
\hline $\ln (n)$ & & & $\begin{array}{r}-0.0091 \\
(0.0626)\end{array}$ & $\begin{array}{c}0.0111 \\
(0.0712)\end{array}$ & \\
\hline In(total education) & & & & $\begin{array}{c}0.0292 \\
(0.0322)\end{array}$ & \\
\hline $\ln (s)-\ln (n+g+\delta)$ & & & & & $\begin{array}{l}0.0432^{*} \\
(0.0222)\end{array}$ \\
\hline Constant & $\begin{array}{c}0.3026^{* * *} \\
(0.0773)\end{array}$ & $\begin{array}{l}0.1809^{*} \\
(0.0925)\end{array}$ & $\begin{array}{l}0.2081 \\
(0.1359)\end{array}$ & $\begin{array}{c}0.0526 \\
(0.1727)\end{array}$ & $\begin{array}{c}0.2524^{* * *} \\
(0.0738)\end{array}$ \\
\hline Observations & 503 & 503 & 503 & 458 & 503 \\
\hline Number of countries & 112 & 112 & 112 & 97 & 112 \\
\hline Hansen & 0.1103 & 0.2671 & 0.3195 & 0.4615 & 0.3522 \\
\hline Difference-in-Hansen & 0.515 & 0.343 & 0.431 & 0.493 & 0.465 \\
\hline AR1 & 0.0001 & 0.0003 & 0.0004 & 0.0005 & 0.0005 \\
\hline AR2 & 0.0561 & 0.1456 & 0.1541 & 0.2579 & 0.1157 \\
\hline Number of instruments & 59 & 59 & 59 & 59 & 59 \\
\hline
\end{tabular}

Notes: The table reports SYS-GMM estimations. All regressions include time dummies; second lags in GMM instruments; robust standard errors in parentheses; $\mathrm{AR}(1)$ and $\mathrm{AR}(2)$ are the $p$-values on the test for the first and second order serial correlation in the differenced error terms respectively; Hansen denotes the $p$-value on the test for the validity of the full instrument set; Difference-in-Hansen denotes the $p$-value for the validity of the set of level-equation. ***,**,* denote significance at the 1,5 , and $10 \%$ levels, respectively. 
From the column 1 to 4 , the standard control variables; and in column 5 only difference of logarithms of saving rate and population growth rate, technological progress, capital depreciation rate $(\ln (s)-\ln (n+g+\delta))$ are added into the model. All models include time-specific dummies. The obtained results show that net inequality and redistribution have significant effects on economic growth in democratic countries. Net inequality has always a negative significant effect, only its effect vanishes with the addition of the control variables. In the first model which includes only initial income, net inequality, and redistribution, both variables are significant. Thus, a rise in the GINI of net income by 10 points leads to a decrease of $1.13 \%$ in the growth of real GDP per capita. On the other, a rise in the redistribution by 10 points leads to an increase of $1.4 \%$ in the growth of real GDP per capita. By adding investment share and population growth as control variables, the impacts of both variables are still significant and in the same direction as in the first model. In column 4, with the addition of total education as a control variable, redistribution impact becomes insignificant, but its coefficients still maintain positive sign. However, in the model which includes this control variable, net inequality has a significant negative effect, while redistribution has a significant positive effect. A rise in the GINI of net income by 10 points leads to a decrease of $0.877 \%$ in the growth of real GDP per capita. On the other hand, a rise in the redistribution by 10 points leads to an increase of $1.3 \%$ in the growth of real GDP per capita. By construction, the residuals of the differenced equation should possess serial correlation, but if the assumption of serial independence in the original errors is warranted, the differenced residuals should not exhibit significant $A R(2)$ behavior. If a significant $\operatorname{AR}(2)$ statistic is encountered, the second lags of endogenous variables will not be appropriate instruments for their current values (Baum, 2013). As expected, in the SYS-GMM estimation, there exists first-order serial correlation and no second-order correlation. The only uncomfortable p-value associated with second-order correlation arises in the baseline model; nevermore, there is still no evidence for second-order serial correlation at the 5\% significance level. In the models estimated with control variables, there is no evidence for second-order serial correlation at the 1, 5, and $10 \%$ levels. The null hypothesis that overidentifying restrictions are valid cannot be rejected as to the p-value of Hansen test. The null hypothesis of the joint validity of the subset of instruments cannot be rejected. The preferred specifications, the p-values on the difference-in-Hansen test are typically above 0.45 (Halter et al. 2014)

An additional check for the DPD estimates' validity is that the estimated coefficient of the lagged dependent variable lies between the values obtained 
from the OLS and WG estimations, as suggested by Bond (2002). This is confirmed by the baseline model as OLS $=-0.0041>\mathrm{SYS}-\mathrm{GMM}=$ $-0.0276>\mathrm{WG}=-0.0703$. The results obtained from the OLS and WG estimations which are presented in the appendix, show that the estimated significance and influence direction of the inequality and the redistribution is approximately the same regardless of the estimation method used. Overall, net inequality impact is still significant and negative on the growth of real GDP per capita. Instead, the impact of redistribution appears also negative but not significant. This might be related that the least squares parameter estimates are biased since the omitted variable is correlated with one of the regressors. The SYS-GMM estimator is unbiased and most efficient if there are endogenous predetermined regressors.

\section{Conclusions}

The estimation results could be interpreted as the net inequality has a negative significant impact on economic growth of the countries. This impact is lower for the whole sample than in democracies. Instead, there is no evidence that redistribution is significant for the whole sample. According to the SYS-GMM results for the whole sample, a rise in the GINI of net income by 10 points leads to a decrease in the growth of real GDP per capita in the range of $0.74-1.10 \%$. However, the redistribution remains insignificant for the whole sample. In democratic countries, both net inequality and redistribution impacts are significant. In democracies, net inequality has a negative effect which is strictly significant, as supported by also OLS and WG estimations. A rise in the GINI of net income by 10 points leads to a decrease in the growth of real GDP per capita in the range of $0.84-1.13 \%$. On the other hand, a rise in the redistribution by 10 points leads to an increase in the growth of real GDP per capita in the range 1.27-1.4\%.

In democracies, redistribution has a positive significant impact on economic growth. The findings are consistent with the fact that in democracies governments tend to significantly redistribute more. The findings are also consistent with the fact that institutions matter as it has been shown in Acemoglu et.al (2009) that democracy has redistributive effects.

The results show that redistribution is not bad for growth when tested simultaneously with net inequality. Especially in democracies, policymaker should decide in favor of redistribution since redistribution may not always create inefficiencies in the growth rate of the output per capita. 


\section{References}

Acemoglu, D., Robinson, J. (2000), Why did the west extend the franchise? Democracy, Inequality, and Growth in Historical Perspective, Q. J. Econ., 115, 1167-1199, DOI: http://dx.doi.org/10.1162/003355300555042.

Acemoglu, D., Robinson, J. (2006), Economic Origins of Dictatorship and Democracy, New York, NY: Cambridge University Press,

DOI: http://dx.doi.org/10.1017/CBO9780511510809.

Acemoglu, D., Johnson, S., Robinson, J., Yared, P. (2009), Reevaluating the modernization hypothesis, J. Monet. Econ., 56, 1043-1058,

DOI: http://dx.doi.org/10.1016/j.jmoneco.2009.10.002.

Acemoglu, D., Naidu, S., Restrepo, P., Robinson, J. (2015), Democracy, redistribution and inequality, in A. B. Atkinson, Handbook of Income Distribution, vol 2B. Chapter 21 (pp. 1885-1996). Amsterdam: Elsevier,

DOI: http://dx.doi.org/10.1016/B978-0-444-59429-7.00022-4.

Acemoglu, D., Ticchi, D., Vindigni, A. (2011), Emergence and persistence of inefficient states, J. Eur. Econ. Assoc., 9(2), 177-208, DOI: http://dx.doi.org/10.1111/j.1542-4774.2010.01008.x.

Aidt, T., \& Dallal, B. (2008), Female voting power: the contribution of women's suffrage to the growth of social spending in Western Europe (1869-1960), Public Choice, 134(3-4), 391-417, DOI: http://dx.doi.org/10.1007/s11127-007-9234-1.

Aidt, T., Dutta, J., \& Loukoianova, E. (2006), Democracy comes to Europe: franchise expansion and fiscal 1830-1938, Eur. Econ. Rev., 50(2), 249-283, DOI: http://dx.doi.org/10.1016/j.euroecorev.2004.07.004.

Aidt, T., \& Jensen, P. (2009a), The taxman tools Up: an event history study of the introduction of the personal income Tax in western Europe, 1815-1941, J. Public Econ., 93, 160-175, DOI: http://dx.doi.org/10.1016/j.jpubeco.2008.07.006.

Aidt, T., \& Jensen, P. (2009b), Tax structure, size of government, and the extension of the voting franchise in western Europe, 1860-1938, Int. Tax Public Fin., 16(3), 362-394, DOI: http://dx.doi.org/10.1007/s10797-008-9069-9.

Aidt, T., \& Jensen, P. (2011), Workers of the World Unite! Franchise Extensions and the Threat of Revolution in Europe, Cambridge Working Papers in Economics, 1102, Faculty of Economics, University of Cambridge, 1820-1938.

Aidt, T., \& Jensen, P. (2013), Democratization and the size of government: evidence from the long 19th century, Public Choice, 157(3-4), 511-542,

DOI: http://dx.doi.org/10.1007/s11127-013-0073-y.

Alesina, A., Rodrik, D. (1994), Distributive politics and economics growth, Q. J. Econ., 109, 465-490, DOI: http://dx.doi.org/10.2307/2118470.

Baltagi, B. (2008), Forecasting with panel data, Journal of Forecasting, 27(2), 153-173.

Barro, R. J. (2000), Inequality and Growth in a Panel of Countries, Journal of Economic Growth, Springer, 5(1), 5-32, DOI: http://dx.doi.org/10.1023/A:1009850119329.

Barro, R. J., Lee, J. (1994), Sources of economic growth, Carnegie-Rochester Conference Series on Public Policy, Elsevier, 40(1), 1-46, DOI: http://dx.doi.org/10.1016/0167-2231(94)90002-7.

Baum, C. (2006), An Introduction to Modern Econometrics using Stata, Stata Press books, StataCorp LP, number imeus January.

Baum, C. (2013), Implementing new econometric tools in Stata, Mexican Stata Users' Group Meetings, Stata Users Group.

Dynamic Econometric Models 17 (2017) 19-39 
Bénabou, R. (1996), Inequality and Growth, CEPR Discussion Papers, 1450, C.E.P.R. Discussion Papers.

Berg, A., Ostry, J., Tsangarides, C. (2014), Redistribution, inequality, and growth, IMF Staff Discussion Note, February.

Bond, S.R. (2002), Dynamic panel data models: A guide to micro data methods and practice, Portuguese Economic Journal, 1(2), 141-162, DOI: http://dx.doi.org/10.1007/s10258-002-0009-9.

Bond, S., Anke, H., Temple, J. (2001), GMM Estimation of Empirical Growth Models, CEPR Discussion Papers, 3048.

Breierova, L., Duflo, E. (2004), The Impact of Education on Fertility and Child Mortality: Do Fathers Really Matter Less Than Mothers?, NBER Working Papers, 10513, National Bureau of Economic Research, Inc.

Brown, D., Hunter, W. (1999), Democracy and social spending in Latin America, 1980-92, Am. Polit Sci. Rev., 93(4), 779-790, DOI: http://dx.doi.org/10.2307/2586112.

Burkhart, R. (1997), Comparative democracy and income distribution: shape and direction of the causal arrow, J. Polit., 59(1), 148-164, DOI: http://dx.doi.org/10.2307/2998219.

Cutler, D., Deaton, A., Lleras-Muney, A. (2006), The Determinants of Mortality, Journal of Economic Perspectives, American Economic Association, 20(3), 97-120, DOI: http://dx.doi.org/10.1257/jep.20.3.97.

De Gregorio, J., Lee, J., (2002), Education and Income Inequality: New Evidence from CrossCountry Data, Review of Income and Wealth, International Association for Research in Income and Wealth, 48(3), 395-416, DOI: http://dx.doi.org/10.1111/1475-4991.00060.

Foellmi, R., \& Zweilmueller, J. (2006), Structural Change and the Kaldor Facts of Economic Growth, Meeting Papers, 342, Society for Economic Dynamics.

Gil, R., Mulligan, C., Sala-i-Martin, X. (2004), Do democracies have different public policies than nondemocracies?, J. Econ. Perspect., 18, 51-74.

Glaeser, E. (2003), Introduction to "The Governance of Not-for-Profit Organizations, NBER Chapters, 1-44.

Gradstein, M., Justman, M. (1999b), The democratization of political elites and the decline in inequality in modern economic growth, in Breizes, E.S., Temin, P. (Eds), Elites, Minorities and Economic Growth, Amsterdam: Elsevier,

Halter, D., Oechslin, M., Zweimüller, J. (2014), Inequality and growth: the neglected time dimension, Journal of Economic Growth, 19(1), 81-104, DOI: http://dx.doi.org/10.1007/s10887-013-9099-8.

Huber, E., Stephens, J. (2012), Democracy and the Left: Social Policy and Inequality in Latin America, University of Chicago Press, Chicago, IL, DOI: http://dx.doi.org/10.7208/chicago/9780226356556.001.0001.

Islam, N. (1995), Growth Empirics: A Panel Data Approach, The Quarterly Journal of Economics, 110(4), 1127-70, DOI: http://dx.doi.org/10.2307/2946651.

Kaldor, N. (1956), Alternative Theories of Distribution, Review of Economic Studies, 23, 83-100.

Kaufman, R., Segura-Ubiergo, A. (2001), Globalization, domestic politics, and social spending in Latin America: a time-series cross-section analysis, 1973-97, World Polit., 53(4), 553-587, DOI: http://dx.doi.org/10.1353/wp.2001.0016.

Kuznets, S. (1955), Economic Growth and Income Inequality, American Economic Review, $65,1-28$.

Lee, C.-S. (2005), Income inequality, democracy, and public sector size, Am. Sociol. Rev., 70(1), 158-181, DOI: http://dx.doi.org/10.1177/000312240507000108. 
Li, H., Squire, L., Zou, H. (1998), Explaining international and intertemporal variations in income inequality, Econ. J., 108(1), 26-43, DOI: http://dx.doi.org/10.1111/1468-0297.00271.

Lindert, P. (1994), The rise of social spending, 1880-1930, Explor. Econ. Hist., 31(1), 1-37, DOI: http://dx.doi.org/10.1006/exeh.1994.1001.

Lott Jr., J., Kenny, L. (1999), How dramatically did women's suffrage change the size and scope of government?, J. Polit. Econ., 107(6), 1163-1198, DOI: http://dx.doi.org/10.1086/250093.

Lucas, R. J. (1988), On the mechanics of economic development, Journal of Monetary Economics, Elsevier, vol. 22(1), 3-42, DOI: http://dx.doi.org/10.1016/0304-3932(88)90168-7.

Mankiw, N.G, Romer, D., Weil, D.N. (1992), A Contribution to the Empirics of Economic Growth, The Quarterly Journal of Economics, Oxford University Press, 107(2), 407-437, DOI: http://dx.doi.org/10.2307/2118477.

Meltzer, A., \& Richard, S. (1981), A rational theory of the size of government, J. Polit. Econ., 89, 914-927, DOI: http://dx.doi.org/10.1086/261013.

Miller, G. (2008), Women's suffrage, political responsiveness, and child survival in American history, Q. J. Econ., 123(3), 1287-1327, DOI: http://dx.doi.org/10.1162/qjec.2008.123.3.1287.

Muller, E. (1988), Democracy, economic development, and income inequality, Am. Sociol. Rev., 53(1), 50-68, DOI: http://dx.doi.org/10.2307/2095732.

Nickell, S. (1981), Biases in Dynamic Models with Fixed Effects, Econometrica, 49(6), 1417-1426, DOI: http://dx.doi.org/10.2307/1911408.

Okun, A. (1975), Equality and Efficiency: the Big Trade-Off, Brookings Institution Press.

Penn World Table, version 8.0. (2013), Retrieved from rug.nl/research/ggdc/data/pwt.

Perotti, R. (1993), Political Equilibrium, Income Distribution, and Growth, Review of Economic Studies, 60(4), 755-776, DOI: http://dx.doi.org/10.2307/2298098.

Persson, T., Tabellini, G. (2003), The Economic Effects of Constitutions, MIT Press, Cambridge.

Phillips, P., Sul, D. (2003), Dynamic panel estimation and homogeneity testing under cross section dependence, Econometrics Journal, 6, 217-259, DOI: http://dx.doi.org/10.1111/1368-423X.00108.

PolityIV Project. (2014), Retrieved from systemicpeace.org/polityproject.html.

Przeworski, A., Alvarez, M., Cheibub, J., Limongi, F. (2000), Democracy and Development: Political Institutions and Material Well-being in the World, 1950-1990, New York, NY: Cambridge University Press,

DOI: http://dx.doi.org/10.1017/CBO9780511804946.

Rodrik, D. (1999), Democracies pay higher wages, Q. J. Econ., 114, 707-738, DOI: http://dx.doi.org/10.1162/003355399556115.

Roodman, D. (2006), How to Do xtabond2: An Introduction to "Difference" and "System" GMM in Stata, Working Papers, 103, Center for Global Development, DOI: http://dx.doi.org/10.2139/ssrn.982943.

Roodman, D. (2009), How to do xtabond2: An introduction to difference and system GMM. The Stata Journal, 9(1), 86-136.

Rosenzweig, M., Binswanger, H. (1993), Wealth, Weather Risk and the Composition and Profitability of Agricultural Investments, Economic Journal, 103(416), 56-78, DOI: http://dx.doi.org/10.2307/2234337.

Scheve, K., Stasavage, D. (2009), Institutions, Partisanship, and Inequality in the Long Run, World Polit., 61, 215-253, DOI: http://dx.doi.org/10.1017/S0043887109000094.

Dynamic Econometric Models 17 (2017) 19-39 
Scheve, K., Stasavage, D. (2010), The conscription of wealth: mass warfare and the demand for progressive taxation, Inter. Organ., 64, 529-561, DOI: http://dx.doi.org/10.1017/S0020818310000226.

Scheve, K., \& Stasavage, D. (2012), Democracy, war, and wealth: lessons from two centuries of inheritance taxation, Am. Polit. Sci. Rev., 106(1), 82-102,

DOI: http://dx.doi.org/10.1017/S0003055411000517.

Simpson, M. (1990), Political rights and income inequality: a cross-national test, Am. Sociol. Rev., 55(5), 682-693.

Sirowy, L., Inkeles, A. (1990), The effects of democracy on economic growth and inequality: a review, Stud. Comput. Inter. Develop., 25, 126-57, DOI: http://dx.doi.org/10.1007/BF02716908.

Solt, F. (2009), Standardizing the world income inequality database, Social Science Quarterly, 90(2), 231-242, DOI: http://dx.doi.org/10.1111/j.1540-6237.2009.00614.x.

Solt, F. (2014), SWIID Version 5.0., Retrieved from the standardized world income inequality database.

Stiglitz, J. (2012), The Price of Inequality: How Today's Divided Society Endangers Our Future, W. W. Norton \& Company.

Thewissen, S. (2013), Is it the income distribution or redistribution that affects growth?, Socio-Economic Review, 12(1), 545-571, DOI: http://dx.doi.org/10.1093/ser/mwt019.

Voitchovsky, S. (2005), Does the Profile of Income Inequality Matter for Economic Growth? Journal of Economic Growth, 10(3), 273-296, DOI: http://dx.doi.org/10.1007/s10887-005-3535-3.

\section{Wpływ nierówności dochodowych i redystrybucji na wzrost w krajach demokratycznych: Dynamiczny model panelowy}

S t r e s z c z e n i e. W artykule analizuje się jednoczesny wpływ nierówności dochodowych i redystrybucji na wzrost dla całej próby oraz dla podgrupy demokratycznych krajów, wykorzystując estymator SYS-GMM na danych panelowych dla okresu od 1960 do 2010. Ogólnie, nierówności dochodowe mają negatywny istotny wpływ na wzrost w kolejnych 5 latach w obydwu grupach podczas gdy wpływ redystrybucji jest istotny tylko w krajach demokratycznych. Wyniki są spójne $\mathrm{z}$ faktem, że poziom redystrybucji jest co do zasady wyższy w krajach pod rządami demokratycznymi.

S ło w a k 1 u c z o w e: demokracja; nierówność; redystrybucja; wzrost gospodarczy 


\section{Appendix}

Box 1. Country list

Angola, Argentina, Armenia, Australia, Austria, Azerbaijan, Burundi, Belgium, Burkina Faso, Bangladesh, Bulgaria, Bahamas, Bosnia and Herzegovina, Belarus, Bolivia, Brazil, Barbados, Botswana, Central African, Republic, Canada, Switzerland, Chile, China, Ivory Coast, Cameroon, Colombia, Cape Verde, Costa Rica, Cyprus, Czech Republic, Germany, Djibouti, Denmark, Dominican Republic, Algeria, Ecuador, Egypt, Spain, Estonia, Ethiopia, Finland, Fiji, France, Gabon, United Kingdom, Georgia, Ghana, Guinea, The Gambia, Guinea-Bissau, Greece, Guatemala, Hong Kong, Honduras, Croatia, Haiti, Hungary, Indonesia, India, Ireland, Iran, Iceland, Israel, Italy, Jamaica, Jordan, Japan, Kazakhstan, Kenya, Kyrgyzstan, Cambodia, Republic of Korea, Laos, St. Lucia, Sri Lanka, Lesotho, Lithuania, Luxembourg, Latvia, Morocco, Madagascar, Mexico, Macedonia, Mali, Malta, Mongolia, Mauritania, Mauritius, Malawi, Malaysia, Namibia, Niger, Nigeria, Nicaragua, Netherlands, Norway, Nepal, New Zealand, Pakistan, Panama, Peru, Philippines, Papua, New, Guinea, Poland, Puerto Rico, Portugal, Paraguay, Moldova, Romania, Russia, Rwanda, Senegal, Singapore, Sierra Leone, El Salvador, Slovak Republic, Slovenia, Sweden, Swaziland, Thailand, Tajikistan, Turkmenistan, Trinidad and Tobago, Tunisia, Turkey, Taiwan, Tanzania, Uganda, Ukraine, Uruguay, United, States, Uzbekistan, Venezuela, Vietnam, Yemen, South Africa, Zambia.

Table 1.1. Descriptive statistics for the whole sample

\begin{tabular}{cccccc}
\hline Variable & $\begin{array}{c}\text { Number } \\
\text { of obs. }\end{array}$ & Mean & SD & Min. & Max. \\
\hline Log of income per capita & 1672 & 8.31719 & 1.295737 & 5.270576 & 11.58735 \\
Average growth of income per & 987 & 0.02216 & 0.031082 & -0.103573 & 0.202936 \\
capita & 1065 & 0.38007 & 0.104694 & 0.162734 & 0.673439 \\
Net inequality & 1057 & 0.07043 & 0.068471 & -0.105736 & 0.303942 \\
Redistribution & 987 & 8.45723 & 1.264281 & 5.191837 & 11.20154 \\
Log of initial income & 988 & 3.04982 & 0.445171 & 1.086359 & 4.303144 \\
Log of investment share & 1065 & 1.86565 & 0.204923 & -0.484576 & 2.652895 \\
Log of population growth & 947 & 1.79102 & 0.57002 & -0.969471 & 2.572392 \\
\hline Log of total education & & & & & \\
\hline
\end{tabular}

Table 1.2. Descriptive statistics for democracies

\begin{tabular}{cccccc}
\hline Variable & $\begin{array}{c}\text { Number } \\
\text { of obs. }\end{array}$ & Mean & SD & Min. & Max. \\
\hline $\begin{array}{c}\text { Log of income per capita } \\
\text { Average growth of income per }\end{array}$ & 1258 & 8.537148 & 1.307467 & 5.398523 & 11.58735 \\
capita & 574 & 0.0238848 & 0.0281755 & -0.0888746 & 0.2029362 \\
Net inequality & 636 & 0.3518494 & 0.1004397 & 0.1672558 & 0.6734387 \\
Redistribution & 634 & 0.0867381 & 0.0704751 & -0.1056635 & 0.3039419 \\
Log of initial income & 574 & 9.079349 & 1.064366 & 5.650741 & 11.20154 \\
Log of investment share & 574 & 3.092598 & 0.3372506 & 1.193682 & 4.303144 \\
Log of population growth & 636 & 1.790123 & 0.1790554 & 0.4518194 & 2.271904 \\
Log of total education & 559 & 2.046362 & 0.4070422 & 0.1049389 & 2.572392 \\
\hline
\end{tabular}


Table 1.3. Descriptive statistics for non-democracies

\begin{tabular}{cccccc}
\hline Variable & $\begin{array}{c}\text { Number } \\
\text { of obs. }\end{array}$ & Mean & SD & Min. & Max. \\
\hline Log of income per capita & 414 & 7.64882 & 0.9974434 & 5.270576 & 10.81616 \\
Average growth of income per & 413 & 0.0197546 & 0.0346132 & -0.1035728 & 0.1386531 \\
capita & 429 & 0.421903 & 0.0966637 & 0.1627338 & 0.6551682 \\
Net inequality & 423 & 0.0459772 & 0.0572967 & -0.1057364 & 0.2690889 \\
Redistribution & 413 & 7.592597 & 0.980364 & 5.191837 & 10.64515 \\
Log of initial income & 414 & 2.990511 & 0.5565421 & 1.086359 & 4.168078 \\
Log of investment share & 429 & 1.977622 & 0.1891687 & -0.4845762 & 2.652895 \\
Log of population growth & 388 & 1.423142 & 0.5705287 & -0.9694707 & 2.379649 \\
Log of total education & & & & &
\end{tabular}

Table 2.1a. The impact of inequality and redistribution on economic growth OLS estimation - The whole sample

\begin{tabular}{|c|c|c|c|c|c|}
\hline Models & $\begin{array}{c}(1) \\
\text { Baseline }\end{array}$ & $\begin{array}{c}\text { (2) } \\
\text { Baseline } \\
+ \text { Ctrls }\end{array}$ & $\begin{array}{c}\text { (3) } \\
\text { Baseline } \\
+ \text { Ctrls }\end{array}$ & $\begin{array}{c}\text { (4) } \\
\text { Baseline } \\
+ \text { Ctrls }\end{array}$ & $\begin{array}{c}\text { (5) } \\
\text { Baseline } \\
+ \text { Ctrls }\end{array}$ \\
\hline In(initial income) & $\begin{array}{l}-0.0005 \\
(0.0012)\end{array}$ & $\begin{array}{c}-0.0030^{* *} \\
(0.0012)\end{array}$ & $\begin{array}{c}-0.0048^{\star \star \star} \\
(0.0013)\end{array}$ & $\begin{array}{c}-0.0076^{\star \star \star} \\
(0.0015)\end{array}$ & $\begin{array}{c}-0.0046^{\star \star \star} \\
(0.0012)\end{array}$ \\
\hline Net inequality & $\begin{array}{c}-0.0523^{* * *} \\
(0.0155)\end{array}$ & $\begin{array}{c}-0.0520^{* * *} \\
(0.0136)\end{array}$ & $\begin{array}{c}-0.0347^{* *} \\
(0.0142)\end{array}$ & $\begin{array}{c}-0.0306^{* *} \\
(0.0137)\end{array}$ & $\begin{array}{c}-0.0385^{* * *} \\
(0.0135)\end{array}$ \\
\hline Redistribution & $\begin{array}{c}-0.0209 \\
(0.0203)\end{array}$ & $\begin{array}{c}-0.0136 \\
(0.0214)\end{array}$ & $\begin{array}{r}-0.0167 \\
(0.0207)\end{array}$ & $\begin{array}{r}-0.0129 \\
(0.0219)\end{array}$ & $\begin{array}{r}-0.0156 \\
(0.0209)\end{array}$ \\
\hline $\ln (i)$ & & $\begin{array}{c}0.0209^{* * *} \\
(0.0031)\end{array}$ & $\begin{array}{c}0.0224^{* * *} \\
(0.0029)\end{array}$ & $\begin{array}{c}0.0226^{* * *} \\
(0.0030)\end{array}$ & \\
\hline $\ln (n)$ & & & $\begin{array}{c}-0.0294^{* *} \\
(0.0116)\end{array}$ & $\begin{array}{c}-0.0200^{*} \\
(0.0115)\end{array}$ & \\
\hline In(total education) & & & & $\begin{array}{c}0.0095^{\star * *} \\
(0.0031)\end{array}$ & \\
\hline $\ln (s)-\ln (n+g+\delta)$ & & & & & $\begin{array}{c}0.0232^{* * *} \\
(0.0028)\end{array}$ \\
\hline Constant & $\begin{array}{c}0.0418^{* * *} \\
(0.0131)\end{array}$ & $\begin{array}{c}-0.0008 \\
(0.0131)\end{array}$ & $\begin{array}{c}0.0602^{* *} \\
(0.0290)\end{array}$ & $\begin{array}{l}0.0504^{*} \\
(0.0269)\end{array}$ & $\begin{array}{c}0.0452^{\star * *} \\
(0.0114)\end{array}$ \\
\hline Observations & 979 & 979 & 979 & 882 & 979 \\
\hline
\end{tabular}

Notes: The table reports OLS estimations. All regressions include time dummies; robust standard errors in parentheses. $* * *, * * * *$ denote significance at the 1,5 , and $10 \%$ levels, respectively. 
Table 2.1b. The impact of inequality and redistribution on economic growth WG estimation - The whole sample

\begin{tabular}{|c|c|c|c|c|c|}
\hline Models & $\begin{array}{c}\text { (1) } \\
\text { Baseline }\end{array}$ & $\begin{array}{c}\text { (2) } \\
\text { Baseline } \\
+ \text { Ctrls }\end{array}$ & $\begin{array}{c}(3) \\
\text { Baseline } \\
+ \text { Ctrls }\end{array}$ & $\begin{array}{c}(4) \\
\text { Baseline } \\
+ \text { Ctrls }\end{array}$ & $\begin{array}{c}\text { (5) } \\
\text { Baseline } \\
+ \text { Ctrls }\end{array}$ \\
\hline In(initial income) & $\begin{array}{c}-0.0378^{* * *} \\
(0.0061)\end{array}$ & $\begin{array}{c}-0.0071^{* * *} \\
(0.0016)\end{array}$ & $\begin{array}{c}-0.0077^{* * *} \\
(0.0016)\end{array}$ & $\begin{array}{c}-0.0114^{* * *} \\
(0.0022)\end{array}$ & $\begin{array}{c}-0.0099^{\star * *} \\
(0.0016)\end{array}$ \\
\hline Net inequality & $\begin{array}{l}0.0115 \\
(0.0262)\end{array}$ & $\begin{array}{c}-0.0475^{\star * *} \\
(0.0156)\end{array}$ & $\begin{array}{c}-0.0385^{* *} \\
(0.0152)\end{array}$ & $\begin{array}{c}-0.0242^{*} \\
(0.0146)\end{array}$ & $\begin{array}{c}-0.0287^{* *} \\
(0.0131)\end{array}$ \\
\hline Redistribution & $\begin{array}{l}0.0500^{*} \\
(0.0282)\end{array}$ & $\begin{array}{l}0.0154 \\
(0.0210)\end{array}$ & $\begin{array}{l}0.0124 \\
(0.0205)\end{array}$ & $\begin{array}{r}-0.0054 \\
(0.0219)\end{array}$ & $\begin{array}{c}0.0066 \\
(0.0214)\end{array}$ \\
\hline $\ln (\mathrm{i})$ & & $\begin{array}{c}0.0224^{* * *} \\
(0.0036)\end{array}$ & $\begin{array}{c}0.0233^{* * *} \\
(0.0034)\end{array}$ & $\begin{array}{c}0.0249^{* * *} \\
(0.0050)\end{array}$ & $\begin{array}{c}0.0227^{* * *} \\
(0.0031)\end{array}$ \\
\hline $\ln (n)$ & & & $\begin{array}{l}-0.0205 \\
(0.0131)\end{array}$ & $\begin{array}{c}-0.0331^{* * *} \\
(0.0090)\end{array}$ & $\begin{array}{r}-0.0170 \\
(0.0130)\end{array}$ \\
\hline In(total education) & & & & $\begin{array}{c}0.0127^{* * *} \\
(0.0041)\end{array}$ & $\begin{array}{c}0.0121^{* * *} \\
(0.0035)\end{array}$ \\
\hline Constant & $\begin{array}{c}0.2948^{* * *} \\
(0.0464)\end{array}$ & $\begin{array}{c}0.0191 \\
(0.0160)\end{array}$ & $\begin{array}{l}0.0577^{*} \\
(0.0334)\end{array}$ & $\begin{array}{c}0.0918^{* * *} \\
(0.0250)\end{array}$ & $\begin{array}{l}0.0522^{*} \\
(0.0304)\end{array}$ \\
\hline Observations & 979 & 979 & 979 & 514 & 882 \\
\hline Number of groups & 164 & 164 & 164 & 101 & 133 \\
\hline
\end{tabular}

Notes: The table reports WG estimations. All regressions include time dummies and country specific fixed effects; robust standard errors in parentheses. $* * *, * *, *$ denote significance at the 1,5 , and $10 \%$ levels, respectively.

Table 3.1a. The impact of inequality and redistribution on economic growth OLS estimation - Sub-group of democracies

\begin{tabular}{|c|c|c|c|c|c|}
\hline Models & $\begin{array}{c}\text { (1) } \\
\text { Baseline }\end{array}$ & $\begin{array}{c}\text { (2) } \\
\text { Baseline } \\
+ \text { Ctrls }\end{array}$ & $\begin{array}{c}\text { (3) } \\
\text { Baseline } \\
+ \text { Ctrls }\end{array}$ & $\begin{array}{c}\text { (4) } \\
\text { Baseline } \\
+ \text { Ctrls }\end{array}$ & $\begin{array}{c}\text { (5) } \\
\text { Baseline } \\
+ \text { Ctrls }\end{array}$ \\
\hline In(initial income) & $\begin{array}{c}-0.0041^{* *} \\
(0.0019)\end{array}$ & $\begin{array}{c}-0.0060^{\star \star \star} \\
(0.0020)\end{array}$ & $\begin{array}{c}-0.0079^{\star \star *} \\
(0.0017)\end{array}$ & $\begin{array}{c}-0.0102^{\star \star \star} \\
(0.0022)\end{array}$ & $\begin{array}{c}-0.0075^{\star \star \star} \\
(0.0019)\end{array}$ \\
\hline Net inequality & $\begin{array}{c}-0.0501^{* *} \\
(0.0213)\end{array}$ & $\begin{array}{c}-0.0553^{* * *} \\
(0.0197)\end{array}$ & $\begin{array}{l}-0.0288 \\
(0.0206)\end{array}$ & $\begin{array}{c}-0.0212 \\
(0.0160)\end{array}$ & $\begin{array}{c}-0.0406^{* *} \\
(0.0196)\end{array}$ \\
\hline Redistribution & $\begin{array}{c}-0.0172 \\
(0.0225)\end{array}$ & $\begin{array}{c}-0.0139 \\
(0.0217)\end{array}$ & $\begin{array}{c}-0.0152 \\
(0.0208)\end{array}$ & $\begin{array}{l}-0.0080 \\
(0.0202)\end{array}$ & $\begin{array}{r}-0.0140 \\
(0.0211)\end{array}$ \\
\hline $\ln (\mathrm{i})$ & & $\begin{array}{c}0.0195^{\star * *} \\
(0.0049)\end{array}$ & $\begin{array}{c}0.0222^{* * *} \\
(0.0049)\end{array}$ & $\begin{array}{c}0.0241^{* * *} \\
(0.0051)\end{array}$ & \\
\hline $\ln (n)$ & & & $\begin{array}{c}-0.0418^{* * *} \\
(0.0079)\end{array}$ & $\begin{array}{c}-0.0301^{* * *} \\
(0.0079)\end{array}$ & \\
\hline In(total education) & & & & $\begin{array}{c}0.0120^{* * *} \\
(0.0038)\end{array}$ & \\
\hline $\ln (s)-\ln (n+g+\delta)$ & & & & & $\begin{array}{c}0.0249 * * * \\
(0.0040)\end{array}$ \\
\hline Constant & $\begin{array}{c}0.0683^{* * *} \\
(0.0213)\end{array}$ & $\begin{array}{l}0.0298 \\
(0.0224)\end{array}$ & $\begin{array}{c}0.1082^{* * *} \\
(0.0252)\end{array}$ & $\begin{array}{c}0.0786^{* * *} \\
(0.0240)\end{array}$ & $\begin{array}{c}0.0692^{* * *} \\
(0.0195)\end{array}$ \\
\hline Observations & 572 & 572 & 572 & 514 & 572 \\
\hline
\end{tabular}

Notes: The table reports OLS estimations. All regressions include time dummies; robust standard errors in parentheses. ***, **, * denote significance at the 1,5 , and $10 \%$ levels, respectively.

Dynamic Econometric Models 17 (2017) 19-39 
Table 3.1b. The impact of inequality and redistribution on economic growth WG estimation - Sub-group of democracies

\begin{tabular}{|c|c|c|c|c|c|}
\hline Models & $\begin{array}{c}\text { (1) } \\
\text { Baseline }\end{array}$ & $\begin{array}{c}\text { (2) } \\
\text { Baseline } \\
+ \text { Ctrls }\end{array}$ & $\begin{array}{c}\text { (3) } \\
\text { Baseline } \\
+ \text { Ctrls }\end{array}$ & $\begin{array}{c}\text { (4) } \\
\text { Baseline } \\
+ \text { Ctrls }\end{array}$ & $\begin{array}{c}\text { (6) } \\
\text { Baseline } \\
+ \text { Ctrls }\end{array}$ \\
\hline In(initial income) & $\begin{array}{c}-0.0703^{* * *} \\
(0.0093)\end{array}$ & $\begin{array}{c}-0.0094^{* * *} \\
(0.0025)\end{array}$ & $\begin{array}{c}-0.0105^{* * *} \\
(0.0019)\end{array}$ & $\begin{array}{c}-0.0114^{* * *} \\
(0.0022)\end{array}$ & $\begin{array}{c}-0.0106^{* * *} \\
(0.0022)\end{array}$ \\
\hline Net inequality & $\begin{array}{c}-0.0059 \\
(0.0426)\end{array}$ & $\begin{array}{c}-0.0714^{* \star *} \\
(0.0202)\end{array}$ & $\begin{array}{c}-0.0462^{* *} \\
(0.0226)\end{array}$ & $\begin{array}{c}-0.0242^{*} \\
(0.0146)\end{array}$ & $\begin{array}{c}-0.0559^{* * *} \\
(0.0196)\end{array}$ \\
\hline Redistribution & $\begin{array}{r}-0.0231 \\
(0.0290)\end{array}$ & $\begin{array}{c}-0.0064 \\
(0.0243)\end{array}$ & $\begin{array}{c}-0.0075 \\
(0.0233)\end{array}$ & $\begin{array}{c}-0.0054 \\
(0.0219)\end{array}$ & $\begin{array}{r}-0.0057 \\
(0.0237)\end{array}$ \\
\hline $\ln (i)$ & & $\begin{array}{c}0.0232^{* * *} \\
(0.0053)\end{array}$ & $\begin{array}{c}0.0249 * * * \\
(0.0050)\end{array}$ & $\begin{array}{c}0.0249^{* * *} \\
(0.0050)\end{array}$ & \\
\hline $\ln (n)$ & & & $\begin{array}{c}-0.0405^{\star * *} \\
(0.0126)\end{array}$ & $\begin{array}{c}-0.0331^{* * *} \\
(0.0090)\end{array}$ & \\
\hline In(total educatinon) & & & & $\begin{array}{c}0.0127^{* * *} \\
(0.0041)\end{array}$ & \\
\hline $\ln (s)-\ln (n+g+\delta)$ & & & & & $\begin{array}{c}0.0275^{* * *} \\
(0.0042)\end{array}$ \\
\hline Constant & $\begin{array}{c}0.6184^{* * *} \\
(0.0717)\end{array}$ & $\begin{array}{c}0.0541^{* *} \\
(0.0238)\end{array}$ & $\begin{array}{c}0.1252^{* * *} \\
(0.0273)\end{array}$ & $\begin{array}{c}0.0918^{* * *} \\
(0.0250)\end{array}$ & $\begin{array}{c}0.0975^{\star * *} \\
(0.0216)\end{array}$ \\
\hline Observations & 572 & 572 & 572 & 514 & 572 \\
\hline Number of groups & 122 & 122 & 122 & 101 & 122 \\
\hline
\end{tabular}

Notes: The table reports WG estimations. All regressions include time dummies and country specific fixed effects; robust standard errors in parentheses. ***,**, * denote significance at the 1,5 and $10 \%$ levels, respectively. 